\title{
Recent advances in radiotherapy and its associated side effects in cancer-a review
}

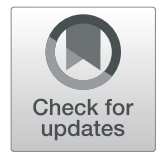

\author{
Gomathi Mohann ${ }^{1}$, Ayisha Hamna T P ${ }^{1}$, Jijo A J ${ }^{2}$, Saradha Devi K M³ ${ }^{3}$ Arul Narayanasamy ${ }^{4}$ and \\ Balachandar Vellingiri ${ }^{1^{*}}$
}

\begin{abstract}
Background: Radiotherapy (RT) is the chief nonsurgical method to control malignant tumors. RT has advanced in both methodological and biological aspects over the past few decades. Though RT is a momentous adjuvant noninvasive technique, it leaves behind some unsympathetic effects. Research is going on to surmount these pessimistic sides of RT.
\end{abstract}

Methods: We made a mini review of recent articles from the period of 2000 to 2017 regarding radiotherapy and its side effects in various types of cancers. The literature review was done by searching in PUBMED, MEDLINE, and SCOPUS.

Results: Here, we spotlight the physiological and genetic risks associated with the cancer patients undergoing RT. We illustrated the course of RT in most prevalent cancers tailored with dosage distribution. Radiation-induced mutation in the patients undergoing RT has been shown with evidence. Further, the major drawbacks like the development of radiation resistance in cancerous cells and secondary malignancies have been discussed. The problems associated with radiation dosage in terms of infertility and rejuvenation of reproductive cells has also been discussed. Finally, we discussed the latest treatment stratagem of RT in cancer.

Conclusion: Cancer treatment will not be accomplished devoid of radiotherapy. But we can brace RT using radiosensitizers and ayurvedic radioprotectors.

Keywords: Radiotherapy, Mutational changes, Infertility, Secondary malignancy, Cancer

\section{Background}

Cancer is the third leading cause of morbidity and mortality worldwide (Thun, DeLancey, Center, Jemal, \& Ward, 2009). Even though there are no specific drugs designed for it, radiotherapy (RT) is the main treatment for cancer and over $60 \%$ of cancer cases require radiation therapy. RT is referred to as irradiation or X-ray therapy. Radiation results in puncturing the DNA of the cancer cells, which inhibits their growth and division thus destroying them. Normal cells neighboring cancer cells can also be affected by radiation. Even though RT is widely used around the world, it leads to many side effects. The effect of radiation and cancer occurrence can be studied from the epidemiological research of atomic

\footnotetext{
* Correspondence: geneticbala2018@rediffmail.com

${ }^{1}$ Human Molecular Genetics and Stem Cell Laboratory, Department of Human Genetics and Molecular Biology, Bharathiar University, Coimbatore, Tamil Nadu 641046, India

Full list of author information is available at the end of the article
}

bomb survivors (Land et al., 2003; Preston, Shimizu, Pierce, Suyama, \& Mabuchi, 2003; UNSCEAR, 2000). Early stage cancers are treated with radiation therapy. The major limitation of radiotherapy is the damage of normal cells surrounding the malignant tumor (Barber et al., 2000; Sprung, Chao, Leong, \& McKay, 2005). Around 5\% of radiosensitive cancer patients are exposed to limited radiation doses to prevent severe radiotherapy side effects. Before treatment, we have to identify predictors for increased radiosensitivity in radiation biology. This process helps to identify patient-specific radiotherapy (Sprung, Davey, Withana, Distel, \& McKay, 2008). The dosages of radiation given to patients are different for different cancers. The amount of radiation given to the patient may depend on the size of tumor, type of surgery, implication of lymph nodes, and qualities of cancer (Dayes et al., 2006). This review describes about the recent radiation therapy treatments meant for 
various cancers and their associated side effects. Studying about the physiological and genetic risks associated with RT is a need of the hour. Hence, this mini review was aimed to collect data on the risks of radiotherapy and to ensure whether ayurvedic formulations will diminish their adverse effects.

\section{Main text}

\section{Physiological risks of radiation treatment in various} cancers

Radiotherapy is a major element in the cancer treatment with approximately $50 \%$ of cases from various types of cancers benefits from RT. According to the Directory of Radiotherapy Centres (DIRAC) data, the worldwide prevalence of cancers and the availability of radiotherapy centers are depicted in Figure 1. Developing countries account for high population but less availability of radiotherapy centers when compared to developed countries.

\section{Breast cancer}

The treatment for breast cancer includes both external beam radiation therapy (EBRT) and internal beam radiation therapy (IBRT). In EBRT, the X-rays are targeted on to the external surface of the cancerous body for few minutes, whereas IBRT is partial breast radiation but consists of limited side effects. Internal beam radiation therapy is also called as brachytherapy, in which radioactive implant is placed near the tumor. About 45005000 cGy dosage is given for 5 weeks to treat cancers present in breast and lymph node areas. Additional dosage of 1000-2000 Gy for 1 week is recommended as a boost (Dayes et al., 2006).The complete dose is not given directly at a time; instead, it is broken down to several daily doses called "fractions." Usually, radiation therapy starts within 3 to 4 weeks after surgery. Common side effects like swelling and heaviness in the breast, fatigue, irritation of skin in the targeted area, which may be mild or intense and discoloration or a bruised appearance (Harris, Lippman, Morrow, \& Osborne, 2014), problems in breastfeeding, lymphedema, acute radiation dermatitis, and a very rare cancer called as angiosarcoma could develop due to radiation therapy treatment for breast cancer (Haruna, Lipsett, \& Marignol, 2017).

\section{Head and neck cancer}

In the case of head and neck cancer, intensity-modulated radiotherapy (IMRT) and brachytherapy are the techniques used predominantly. Intensity-modulated radiotherapy is the sophisticated form of three-dimensional conformal radiation therapy (3D-CRT), which can modulate the intensity of radiation at the sharply conformal target without damaging the surrounding normal tissues (Eisbruch, Ten Haken, Kim, Marsh, \& Ship, 1999; Nutting, Dearnaley, \& Webb, 2000) Brachytherapy can be of two types, intracavitary (implant placed in a cavity) and interstitial radiation (implant placed in or near cavity, other than body cavity). The dosage of 56-70 Gy during the early stage of head

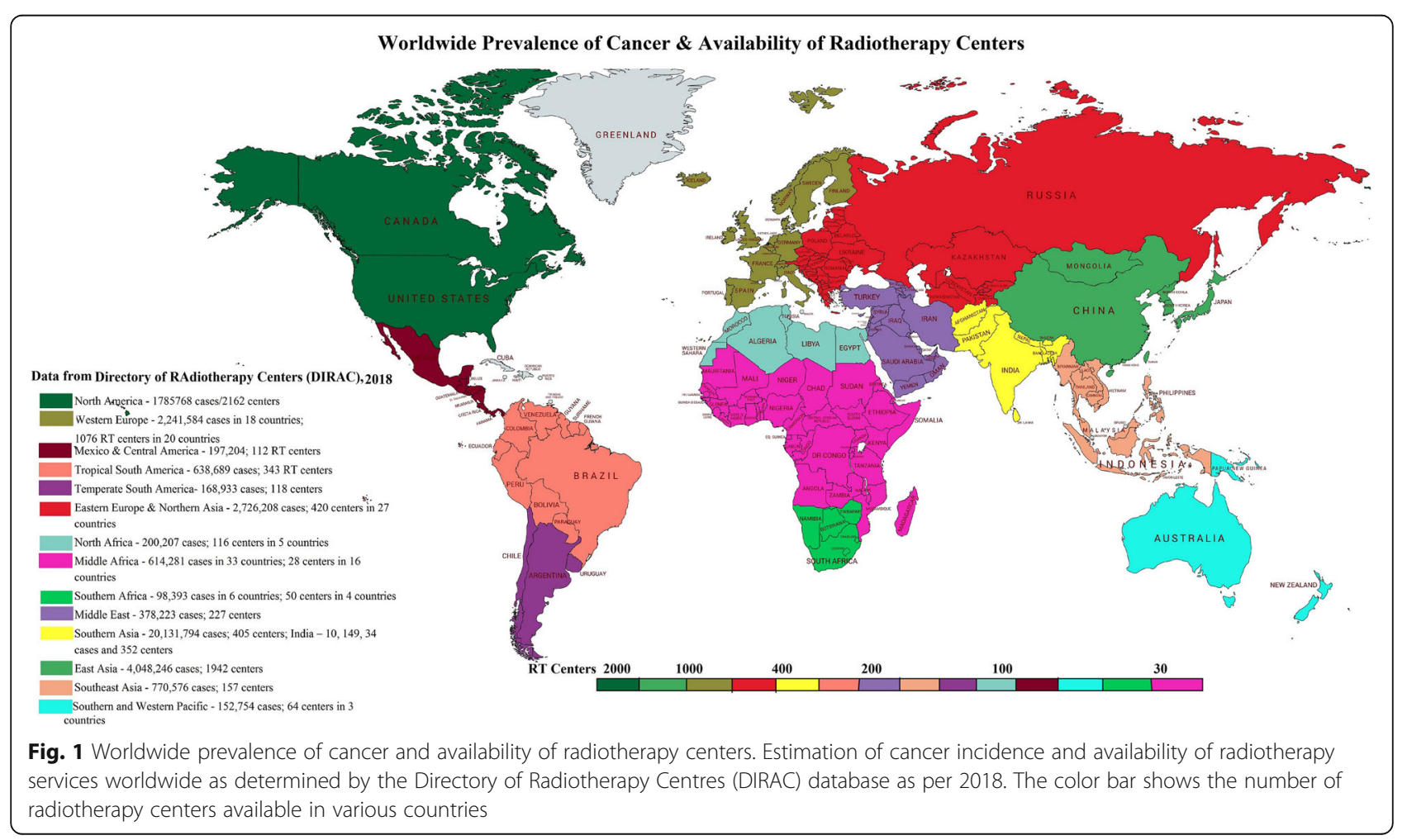


and neck cancer is advisable. It can be administered at the level of 2 Gy per fraction daily for 6 weeks. Depending on the type of radiation, the dosage can vary from 56 to 66 Gy (Pradier et al., 2004). Trouble in swallowing, soreness, hair loss, and tooth decay are the side effects. A late complication leads to xerostomia, a poor dental condition, compromised oral hygiene, altered taste sensation, nutritional deficiency, poor sleep quality, and impaired speech function (Bjordal, Kaasa, \& Mastekaasa, 1994). A dosage of 35 Gy leads to permanent loss of function of salivary glands and results in xerostomia (Yeh, 2010).

\section{Liver cancer}

External beam radiation therapy, 3D-CRT, IMRT, and stereotactic body radiation therapy (SBRT) are the recent radiotherapy techniques to treat liver cancer. In SBRT, high doses of radiation are delivered at a particular target without damaging the surrounding normal tissues. In 3D-CRT, radiation beams are delivered in multiple small volumes targeted at the 3D shape tumor (Dawson et al., 2000). These techniques also reflect many side effects. In liver cancer, the radiation therapy dosage taken is nearly $70 \mathrm{~Gy}$. If the radiation therapy doses of 30-33 Gy are applied to the entire liver, 5\% risk of radiation-induced liver disease (RILD) will occur but a dose of 40 Gy leads to $50 \%$ risk of RILD (Fuss, Salter, Herman, \& Thomas Jr, 2004). Common side effects include nausea, vomiting, gastritis, upper abdominal pain, gastric or duodenal bleeding, and fatigue (Dawson et al., 2000; Lawremce et al., 1991; McGinn et al., 1998; Robertson et al., 1993).

\section{Non-melanoma skin cancer}

Broadly used treatments for non-melanoma skin cancer include EBRT, brachytherapy, and superficial radiation therapy (SRT) (Rong, Zuo, Shang, \& Bazan, 2015). A total dosage of $45 \mathrm{~Gy}$ is delivered in $3 \mathrm{~Gy}$ doses of 15 fractions for 3 weeks period. Erythema and mild discomfort is seen during treatment, but systemic side effects are rare. Late complications such as hyper- or hypopigmentation, telangiectasias, and atrophy are seen (McGregor, Minni, \& Herold, 2015).

\section{Thyroid cancer}

Thyroid cancer is treated with EBRT of a standard dose of $60 \mathrm{~Gy}$ in 30 fractions (Brierley, 2011). Radioactive iodine therapy (radioiodine or iodine-131) is used to detect and kill the thyroid cells, which are not removed by surgery. Swelling or pain of salivary gland, headache, vertigo, insomnia, vocal cord paralysis, fatigue, general malaise, foreign body sensation, body numbness, and urinary tract infection symptoms are some of the side effects (Lu, Shan, Li, \& Lu, 2016).

\section{Colorectal cancer}

For colorectal cancer, EBRT is considered as an effective treatment at stage IV. The dosage ranges from 40 to 74 Gy with 1.8-2.0 Gy per fraction being administered to the colorectal patients (Bae et al., 2011). Possible side effects include nausea, bowel incontinence or stool leakage, fatigue, tiredness, rectal irritation, skin irritation, bladder irritation along with burning sensation or pain while urinating, diarrhea, painful bowel movements, and blood in the stool. Besides, sexual problems such as vaginal irritation in women and erection issues in men are also encountered due to radiation therapy (Van Schaeybroeck et al., 2005).

\section{Prostate cancer}

In case of prostate cancer, positron emission tomography (PET) with prostate-specific membrane antigen (PSMA)-based EBRT is the most widely used technique with high specificity and sensitivity for the detection of lymph nodes and metastases. External beam radiation therapy for prostate cancer patients resulted in developing obstructive voiding symptoms and it negatively affects their quality of life (Hoppe et al., 2014; Sanda et al., 2008). The radiation dosage of $70.2 \mathrm{~Gy}$ or an increased dosage of $79.2 \mathrm{~Gy}$ can be used to treat prostate cancer at the initial stage. The booster dose of 19.8-28.8 Gy can be administered after surgery or later stage of cancer. Side effects include radiation proctitis, rectal bleeding, diarrhea, hematochezia, radiation cystitis, impotence, fatigue, lymphedema, and erection problems (Vicini, Kestin, Ghilezan, \& Martinez, 2006; Zietman et al., 2005).

\section{Lung cancer}

Lung cancer treatment includes two types of EBRT such as 3D-CRT and IMRT. Even though the RT dose of 60 Gy causes certain side effects, it is given as standard dosage for lung cancer in 4-5 fractions (Ming et al., 2016). If the dosage is increased to $70 \mathrm{~Gy}$, it leads to severe risks of shortness of breath, difficulty in swallowing, shoulder stiffness, cough, fever, breast or nipple soreness, and radiation pneumonitis, which can occur between 2 weeks to 6 months after radiotherapy and decreases survival rates (Gensheimer \& Loo, 2017).

\section{Endometrial cancer}

Widely used treatments for endometrial cancer include adjuvant vaginal brachytherapy and pelvic EBRT. Total dosage of $46 \mathrm{~Gy}$ can be delivered as 23 fractions for 5 days per week to treat early stage endometrial cancer. Also, doctors recommend an additional dosage of 10002000 Gy as a boosting dosage for 1 week. Bowel incontinence, rectal bleeding, bladder irritation, and diarrhea are some common side effects accompanied by changes 
in menstruation, vaginal itching, burning, dryness, and infertility (Kellas-Sleczka, Wojcieszek, \& Białas, 2012).

\section{Ovarian cancer}

For ovarian cancer, referring to the stage of the disease, four types of RT are carried out such as adjuvant RT at early stage, consolidative RT at advanced stage, salvage $\mathrm{RT}$ at recurrent disease, and palliative RT at metastatic disease. A total dosage of 22.5-33 Gy in 10-24 fractions for 5 weeks is administered for the abdomen region and an additional dose of 40-45 Gy delivered to the pelvis. For epithelial ovarian cancer, RT treatment includes EBRT to the entire abdominal cavity with $22-24$ Gy in 22-24 fractions followed on the pelvis with 23.4-21.6 Gy in 12-13 fractions. Side effects such as radiation enterocolitis, bowel discomfort, and vaginal irritation were seen (Rai, Bansal, Patel, \& Sharma, 2014).
Risks and remedies of radiation therapy in various cancers are collected in Table 1.

\section{Genetic mutations occurring after radiation therapy in cancer patients}

In cancer patients, chromosomal abnormalities are one of the major adverse effects caused by RT. Structural chromosomal aberrations and numerical or copy number alterations are seen in cancer patients, who have undergone RT (Grade, Difilippantonio, \& Camps, 2015). The genes responsible for cell proliferation and cellular repair have undergone mutation, accumulated in the genome resulting in cancer (Kim, Chandrasekaran, \& Morgan, 2006; Klein, Casey, \& Silverman, 2006; Sandberg, 1991). The increase or decrease in the frequency of chromosomal aberration is proportional to the radiation dose (Sprung et al., 2005). Dicentric chromosome, an

Table 1 Risk and remedies of radiation therapy in various cancers

\begin{tabular}{|c|c|c|c|c|}
\hline $\begin{array}{l}\text { S. } \\
\text { no. }\end{array}$ & $\begin{array}{l}\text { Type of } \\
\text { cancer }\end{array}$ & $\begin{array}{l}\text { Radiation } \\
\text { dosage } \\
\text { (Gy) }\end{array}$ & Associated risks & Potential Ayurvedic remedies \\
\hline 1 & $\begin{array}{l}\text { Breast } \\
\text { cancer }\end{array}$ & $45-50$ & $\begin{array}{l}\text { Swelling and heaviness in the breast, fatigue, irritation of } \\
\text { the skin in the targeted area, and discoloration or a } \\
\text { bruised appearance. Problems in breastfeeding, } \\
\text { lymphedema, acute radiation dermatitis, and a very rare } \\
\text { cancer called as angiosarcoma }\end{array}$ & $\begin{array}{l}\text { Treatment with pentoxifylline and topical purified honey } \\
\text { ointment rescued skin-related problems (Shoma et al., } \\
\text { 2010) }\end{array}$ \\
\hline 2 & $\begin{array}{l}\text { Head and } \\
\text { Neck Cancer }\end{array}$ & $56-66$ & $\begin{array}{l}\text { Trouble in swallowing, soreness, hair loss, tooth decay, } \\
\text { xerostomia, oral mucositis, altered taste sensation, } \\
\text { nutritional deficiency, poor sleep quality, and impaired } \\
\text { speech function }\end{array}$ & $\begin{array}{l}\text { Thyme honey showed better treatment for xerostomia } \\
\text { and mucositis (Charalambous et al., 2017). }\end{array}$ \\
\hline 3 & Liver Cancer & 70 & $\begin{array}{l}\text { Nausea, vomiting, gastritis, upper abdominal pain, gastric } \\
\text { or duodenal bleeding, and fatigue }\end{array}$ & $\begin{array}{l}\text { Ginger and metoclopramide treatment are efficient to } \\
\text { treat nausea and vomiting (Sontakke, Thawani, \& Naik, } \\
\text { 2003). Arogya-wardhani used to rescue abnormal liver } \\
\text { functions (Antarkar, 1980) }\end{array}$ \\
\hline 4 & $\begin{array}{l}\text { Non- } \\
\text { melanoma } \\
\text { Skin Cancer }\end{array}$ & 45 & Erythema, dermatitis, and atrophy & $\begin{array}{l}\text { Turmeric and sandalwood containing cream can treat } \\
\text { dermatitis (Palatty et al., 2014) }\end{array}$ \\
\hline 5 & $\begin{array}{l}\text { Thyroid } \\
\text { Cancer }\end{array}$ & 60 & $\begin{array}{l}\text { Swelling or pain of salivary gland, headache, vertigo, } \\
\text { insomnia, vocal cord paralysis, fatigue, general malaise, } \\
\text { foreign body sensation, body numbness, and urinary tract } \\
\text { infection }\end{array}$ & $\begin{array}{l}\text { Inhalation of blended } 1 \mathrm{ml} \text { lemon and } 0.5 \mathrm{~mL} \text { of ginger } \\
\text { essential oils showed significant improvement in salivary } \\
\text { gland secretion (Nakayama, Okizaki, \& Takahashi, 2016) }\end{array}$ \\
\hline 6 & $\begin{array}{l}\text { Colorectal } \\
\text { Cancer }\end{array}$ & $40-74$ & $\begin{array}{l}\text { Nausea, bowel incontinence or stool leakage, fatigue, } \\
\text { tiredness, rectal irritation, skin irritation, bladder irritation } \\
\text { along with burning sensation or pain while urinating, } \\
\text { diarrhea, blood in stool, vaginal irritation in women, and } \\
\text { erection issues in men are seen }\end{array}$ & $\begin{array}{l}\text { Navjeevan Rasayana, Tamra Bhasma, Swarna Bhasma, } \\
\text { Hirak Bhasma, Agni Rasayana, Sutendra Rasayana, and } \\
\text { Pranwallabhrasayana are improved QoL of colon cancer } \\
\text { (Bendale et al., 2015) }\end{array}$ \\
\hline 7 & $\begin{array}{l}\text { Prostate } \\
\text { Cancer }\end{array}$ & 70.2 & $\begin{array}{l}\text { Radiation proctitis, rectal bleeding, diarrhea, } \\
\text { hematochezia, radiation cystitis, impotence, fatigue, } \\
\text { lymphedema, and erection problems }\end{array}$ & $\begin{array}{l}\text { Vicenin } 2 \text { having chemo-radioprotective effect in prostate } \\
\text { cancer cells (Malvika, Satyapal, Lal, \& Mita, 2016) }\end{array}$ \\
\hline 8 & Lung Cancer & 60 & $\begin{array}{l}\text { Shortness of breath, difficulty in swallowing, shoulder } \\
\text { stiffness, cough, fever, breast or nipple soreness, and } \\
\text { radiation pneumonitis }\end{array}$ & $\begin{array}{l}\text { Navjeevan Rasayana rescued laryngeal functions like } \\
\text { voice, breathing, and swallowing (Bendale, Bendale, Birari- } \\
\text { Gawande, Kadam, \& Gund, 2015) }\end{array}$ \\
\hline 9 & $\begin{array}{l}\text { Endometrial } \\
\text { Cancer }\end{array}$ & 46 & $\begin{array}{l}\text { Bowel incontinence, rectal bleeding, bladder irritation, } \\
\text { diarrhea, changes in menstruation, vaginal itching, } \\
\text { burning, dryness, and infertility }\end{array}$ & $\begin{array}{l}\text { Ficus hispida is used as an anti-inflammatory and also } \\
\text { treat hemorrhage (Ali \& Chaudhary, 2011) }\end{array}$ \\
\hline 10 & $\begin{array}{l}\text { Ovarian } \\
\text { Cancer }\end{array}$ & $22.5-33$ & Radiation cystitis, bowel discomfort, and vaginal irritation & $\begin{array}{l}\text { Sandalwood oil and lupeol are used to treat genitourinary } \\
\text { tract infection and cystitis (Kuvar, Lambole, Shah, Shah, \& } \\
\text { Shah, 2013; Misra \& Dey, 2013) }\end{array}$ \\
\hline
\end{tabular}


abnormal chromosome with two centromere or translocated chromosomes, is an estimated risk of radiation dosage done by scoring chromosomal aberrations (Abe et al., 2016). In dicentric chromosomes, although the cells are unstable and cannot be passed through repeated mitotic division, the translocated chromosomes are stable. Dicentric chromosomes and translocations are produced equally in human peripheral blood after radiation therapy (Kanda, 1996; Zhang \& Hayata, 2003). Radiation therapy leads the cells to form free radicals resulting in DNA breakage, base pair alteration, and DNA-DNA cross-linking. In general, the harmful effect of radiation causes defects during DNA replication and affects the repairing mechanism of DNA damage (Lorimore \& Wright, 2003). New studies state that the mutation caused by radiation therapy in cellular DNA can get transmitted and expressed in the progeny surviving cell (Tomita \& Maeda, 2015). Genomic instability arises with radiation-induced bystander effect, which causes DNA damage, chromosomal instability, mutation, and apoptosis (Kadhim et al., 2013; Kaplan, Limoli, \& Morgan, 1997; Little, 2003; Morgan, Day, Kaplan, McGhee, \& Limoli, 1996). Very low dosage of radiation for a long period of exposure can also cause chromosomal aberrations (Cho et al., 2015), which include aneuploidy (Heim, Lench, \& Swift, 1992), gene deletion (Kadhim et al., 1992), and stable and unstable aberrations (Little, 2003). The most common type is aneuploidy occurring as a result of mitotic chromosome segregation (Malmanche, Maia, \& Sunkel, 2006), (Sen, 2000).

\section{Secondary malignancies after radiation therapy}

Secondary malignancies are the cancers occurring even after the initial treatment of the primary cancer. Radiotherapy with or without chemotherapy is a potential risk factor for secondary malignancies (Lin, 2016). Though ionizing radiations are used to destroy cancerous tissues, the incidence of second malignant neoplasm (SMN) arises among long-term survivors. Hence, ionizing radiations are carcinogenic agents. With improved survival rates, the increasing SMN attributable to radiation therapy has become a major concern among long-term survivors (de Gonzalez et al., 2011; Tubiana, 2009; Xi et al., 2013). Recurrent malignancies need to be detected early to reduce further complications and to increase the survival rate (Benveniste et al., 2013). Radiotherapy and tumor microenvironment affect "naïve" cells and tissues by inducing the secretion of inflammatory factors such as cytokines and free radicals. Then, the activated immune system directly or indirectly induces oxidative DNA damage into the environment. Therefore, monitoring DNA damage as early as possible enables the understanding of the underlying mechanisms of non-targeted effects (Sprung et al., 2015). Three characteristic features are exhibited by cancer that occurs due to radiation therapy. First, histological features of primary and secondary cancers are different. Second, the secondary cancers are present within the area, which has been previously treated with radiation. Third, secondary cancer consists of a latency period of 5 years. The main cause of secondary malignancy is DNA damage during the treatment of primary cancer. In breast cancer patients, the chance of recurrence of secondary malignancy is much reduced. Secondary cancers occurring due to radiotherapy is only a small proportion, when compared to the remaining factors like lifestyle, carcinogenic exposure, and genetics (de Gonzalez et al., 2011).

\section{Infertility after radiation therapy}

Women undergoing $\mathrm{RT}$ in the abdomen or pelvis region are prone to fertility issues based on the dosage. High dose of radiation therapy causes the destruction of eggs in the ovary and also leads to early menopause. Although RT causes decreased fertility in women, the site of exposure will also tend to attribute to future fertility. Abdominopelvic radiation therapy leads to side effects such as miscarriage, preterm labor, low birth weight, and placental abnormality (Cruz \& Bellver, 2014). When radiation is directed into the uterus for treating endometrial cancer, the ovaries absorb a high dose of radiation and this leads to $5 \%$ infertility and side effects such as miscarriage, low birth weight in infants, and premature birth (Balcerek, Reinmuth, Hohmann, Keil, \& Borgmann-Staudt, 2012; Gnoth et al., 2005; Habbema et al., 2009; Wo \& Viswanathan, 2009). Radiation in the brain affects the pituitary gland, which in turn will affect ovulation rate by altering hormonal balance. The dosage and area of exposure determine the fertility rate. Craniospinal irradiation causes hormonal changes, which can pose problems related to pregnancy later in life. Cranial radiotherapy causes dysfunction in the hypothalamic-pituitary axis, leading to uterine damage or abnormal ovulation. The cranial irradiated patients undergo abnormality in gonadal axis (Ash, 1980). The dose of radiation is related to the age of patients. For example, 400 cGy causes 30\% infertility in young women; instead, the same dose causes $100 \%$ sterility in women aged above 40 years.

In males, fractionated irradiation of testes may be more harmful than acute, at least up to a total dosage of 600 cGy. Fractionated dosage (FD) greater than 35 cGy causes aspermia and the recovery time depends upon the dosage, but if FD is greater than 200 cGy, the probability of aspermia is high (Grover et al., 2012; Zaletel, Todorovski, \& Jereb, 2012). Primary testicular damage occurs when radiation is directly aimed near the testicles. Spermatogonia are more sensitive to radiation. Even a dosage as low as 600 cGy causes irreversible damage, 
while less than this dosage causes a drop in number and quality of sperm produced. Secondary or indirect testicular failure occurs following RT to the brain. This causes damage to the pituitary gland and results in the imbalance of hormones such as FSH and LH, and both of these hormones are needed for stimulating spermatogonia and Leydig cells. This will also cause a decreased level of testosterone production. During prostatectomy, both prostate gland and nearby seminal vesicles are removed. Together with prostate gland, they carry sperm down to the urethra and out of the penis during ejaculation. Damage caused by radiation therapy leads to impossible ejaculation, so the sperm does not get out of the body and cannot reach the ovum for fertilization to occur (Orth et al., 2014). An individual receiving higher dose of radiation therapy and chemotherapy needs to wait for a longer period to regain sperm production. Factors such as existing fertility issue and age also affect fertility. Younger boys who are exposed to RT before puberty does not have much reduction in sperm production, but stronger treatment causes premature infertility. Leydig cells are relatively resistant to the damaging effect of RT. The normal function of Leydig cells remains normal when treated with doses less than 2400 cGy; the Leydig cells produce testosterone, which is required for normal sexual activity (Nutting et al., 2001).

\section{Recent treatment strategies in radiotherapy}

Recently, most widely used advanced therapy for treatment of cancer includes intensity-modulated radiotherapy (IMRT) and image-guided radiotherapy (IGRT) (Nutting et al., 2001). Introduction of IMRT technique suggests that local administration of radiation will improve the target covering and thereby decreasing the damage to the surrounding cells. Modern radiotherapy technique has less toxicity than the classical radiotherapy technique (Bortfeld, 1999; Chandra et al., 2005; Kole, Aghayere, Kwah, Yorke, \& Goodman, 2012; Nguyen et al., 2012). Image-guided radiotherapy is the radiation treatment using X-rays which includes the scanning of the tumor site such that the radiotherapy field consists of the tumor site as well as the borderline. It gives an idea about the size, shape, and position of the cancer cells as well as the surrounding tissues. Intensity-modulated radiotherapy and image-guided radiotherapy cause curative and acceptable complications other than pre-existing harmful effects in locally advanced esophageal cancer (Lin et al., 2012). Variations in IMRT treatment is used for optimal control by decreasing harm to neighboring cells. During complex treatments like distal esophageal cancer, the use of IMRT is much better than 3D-CRT (Bujold, Craig, Jaffray, \& Dawson, 2012; Dolezel et al., 2015). Hence, novel methods such as IMRT and IGRT have become better treatment methods with fewer side effects. Intensity-modulated radiotherapy can deliver steep dosage, which will have important clinical aspects. This also makes IMRT more accurate and less harmful to the nearby tissues. Image-guided radiotherapy act as a quality assurance for high-quality IMRT (Grills et al., 2008), while IMRT used along with 3D-CRT improves target specificity and reduces the risk of myelopathy. Intensity-modulated radiotherapy does not only spare the organs at risk but also it irradiates the different doses of radiation for different tumors commonly known as simultaneous integrated boost technique (De Ruysscher et al., 2010). Recent technology has reduced planning target volume margins, which include cone beam computed tomography (CBCT) and 4D-CT simulation (Sangro, Iñarrairaegui, \& Bilbao, 2012). Clinically, more accurate calculations have been obtained by using IMRT and proton beam therapy (PBT) techniques (Yu \& Kim, 2015). Emergence of carbon-ion radiotherapy (CIRT) has an acceptable value, because it enables sufficient volume of radiation to the tumor site along with lesser dose to the surrounding normal tissues by means of carbon ions, which have higher atomic mass and can penetrate into the tumor and give better results than other particles (Tsujii, 2017). Transarterial radioembolization (TARE) technique is accomplished by the use of high-energy radioisotope of yttrium $90(\mathrm{Y})$ pure beta rays loaded into $25-32.5 \mu \mathrm{M}$-sized microspheres and get inserted into tumors (Kennedy et al., 2007; Liapi \& Geschwind, 2010). Transarterial radioembolization causes less damage to the vascular system (Lau et al., 2013; Sato et al., 2006) by means of microembolisation (minimal to moderate embolisation) (Budach, Hehr, Budach, Belka, \& Dietz, 2006; Orth et al., 2014; Salem et al., 2010). Elderly patients having NSCLC (non-small cell lung cancer), when treated with stereotactic ablative radiotherapy (SABR), show an improvement in the results. In $S A B R$, the radiation beams meet at different parts of the tumor so that maximum intensity of radiation can reach the site. Hence, the tumor receives a high dose of radiation within a short range of area. Combination of chemotherapy with radiotherapy has attained a great achievement in the treatment of cancer (Begg, Stewart, \& Vens, 2011). Apart from this, the combination of radiotherapy and molecularly designed agents to target specific cancer gives better outcomes. Stratification of the patient will result in the effectiveness of this type of technique and the side effects will be reduced (Niyazi et al., 2011). Introduction of smart radiotherapy biomaterials (SRBs) such as radio-opaque fiducial markers into the site of the tumor-bearing organs will reduce the harmful effect to the neighboring cells. These markers consist of radio-opaque materials, such as gold or a metal alloy for determining the cancer 
site. The main advantage of this technique is that it has minimal immunogenicity and toxicity (Bair, Bair, \& Viswanathan, 2015). Another radiation technique is RapidArc technique or volumetric modulated arc therapy (VMAT), which gives high conformal dose distribution through a complete rotation of about $360^{\circ}$. Compared with conventional radiation therapy and IMRT, VMAT gives more accurate and less damage to the surrounding tissue with better advantage (Clivio et al., 2009; Cozzi et al., 2008; Palma et al., 2008; Shaffer et al., 2010; Verbakel et al., 2009). Volumetric modulated arc therapy is the developed form of IMRT. VMAT is a developing clinical therapy technique, which cannot be used as a curative method for all clinical cases (Holt, van Vliet-Vroegindeweij, Mans, Belderbos, \& Damen, 2011), but it plays a vital role in the improvement of the quality of life.

\section{Fortification of risks of radiotherapy}

The adverse effects of RT can be overcome by using radiosensitizers and radioprotectors ( $\mathrm{Lu}$ et al., 2016). Radiosensitizers are the compounds that can sensitize the tumor target itself and eliminate the free radicals produced from the cell damage. Hyperbaric oxygen, carbogen, nicotinamide, metronidazole, hypoxic cell cytotoxic agents including mitomycin-c, tirapazamine, motexafin gadolinium, taxanes, and irinotecan are some of the radiosensitizers used to increase the efficacy of RT treatment. Radioprotectors are mostly antioxidants that can be used before or at the time of RT to protect normal cells. Amifostine (Ethyol) and nitroxides are some examples of radioprotectors (Prasanna et al., 2015; Raviraj, Bokkasam, Kumar, Reddy, \& Suman, 2014).

Ayurvedic radioprotectors are now provoking the eyes of researchers and therapists because of their zero side effects. Many preclinical and clinical studies are ongoing with the radioprotective effects of plants. Studies reported that the ayurvedic formulations such as Triphala, Amritaprasham, Chyavanprasha, Ashwagandha Rasayana, Brahma Rasayana, and Narasimha Rasayana are effective radioprotectors by means of scavenging free radicals, decreasing oxidative stress, inhibiting DNA damage, and regenerating bone marrow progenitors, anti-inflammatory chemoprotection, and immunomodulatory mechanisms (Baliga, Meera, Vaishnav, Rao, \& Palatty, 2013).

\section{Conclusions}

Development of science and technology introduces new techniques for the effective treatment of cancer. Among various methods of radiation therapy, some are already being used and others need more study for their widespread use. Though new therapies have been developed to treat cancer, RT remains an indispensable technique in the management and control of most of the cancer types. It also plays a vital role as an organ-preserving method by reducing the need and chance of surgery. Especially, using ayurvedic drugs in combination with radiotherapy are found to be a better management.

\section{Abbreviations}

3D-CRT: Three-dimensional conformal radiation therapy; CBCT: Cone beam computed tomography; CIRT: Carbon-ion radiotherapy; EBRT: External beam radiation therapy; FD: Fractionated dosage; IBRT: Internal beam radiation therapy; IGRT: Image-guided radiotherapy; IMRT: Intensity-modulated radiotherapy; NSCLC: Non-small cell lung cancer; PBT: Proton beam therapy; PET: Positron emission tomography; PSMA: Prostate-specific membrane antigen; RILD: Radiation-induced liver disease; RT: Radiotherapy; SABR: Stereotactic ablative radiotherapy; SBRT: Stereotactic body radiation therapy; SMN: Second malignant neoplasm; SRB: Smart radiotherapy biomaterials; SRT: Superficial radiation therapy; TARE: Transarterial radioembolization; VMAT: Volumetric modulated arc therapy

\section{Acknowledgements}

The authors would like to thank the authorities of Bharathiar University, India for providing the necessary facilities to conduct this review.

\section{Funding}

This work was supported by University Grants Commission - National Fellowship for Scheduled Caste Candidates Mrs. Gomathi, (Award number and date: F1-17.1/2017-18/RGNF-2017-18-SC-TAM-35724 /(SA-III/Website) 02/08/2017).

\section{Availability of data and materials}

Data and relevant materials were obtained from NCBI-PUBMED central, MEDLINE, Scopus and Google scholar.

\section{Authors' contributions}

GM and BV contributed to the study design. GM, BV, AHTP, JAJ, SDKM, and AN contributed to the manuscript preparation. BV approved the manuscript. All authors read and approved the final manuscript.

Ethics approval and consent to participate

Not applicable.

Consent for publication

Not applicable

\section{Competing interests}

The authors declare that they have no competing interests.

\section{Publisher's Note}

Springer Nature remains neutral with regard to jurisdictional claims in published maps and institutional affiliations.

\section{Author details}

${ }^{1}$ Human Molecular Genetics and Stem Cell Laboratory, Department of Human Genetics and Molecular Biology, Bharathiar University, Coimbatore, Tamil Nadu 641046, India. ${ }^{2}$ Post Graduate and Research Department of Zoology, Sree Narayana College, Cherthala, Alappuzha district, Kerala 688523, India. ${ }^{3}$ Department of Biochemistry, Bharathiar University, Coimbatore 641046, India. ${ }^{4}$ Disease Proteomics Laboratory, Department of Zoology, Bharathiar University, Coimbatore, Tamil Nadu 641046, India.

Received: 6 September 2018 Accepted: 31 January 2019

Published online: 27 February 2019

\section{References}

Abe, Y., Miura, T., Yoshida, M. A., Ujiie, R., Kurosu, Y., Kato, N., ... Inamasu, T. (2016). Analysis of chromosome translocation frequency after a single CT scan in adults. Journal of Radiation Research, 57(3), 220-226. 
Ali, M., \& Chaudhary, N. (2011). Ficus hispida Linn.: A review of its pharmacognostic and ethnomedicinal properties. Pharmacognosy Reviews, 5(9), 96.

Antarkar, D. S. (1980). A double-blind clinical trial of Arogya-wardhani-an Ayurvedic drug-in acute viral hepatitis. Indian Journal of Medical Research, 72, 588-593.

Ash, P. (1980). The influence of radiation on fertility in man. The British Journal of Radiology, 53(628), 271-278.

Bae, S. H., Park, W., Choi, D. H., Nam, H., Kang, W. K., Park, Y. S., ... Kim, H. C. (2011). Palliative radiotherapy in patients with a symptomatic pelvic mass of metastatic colorectal cancer. Radiation Oncology, 6(1), 52.

Bair, R. J., Bair, E., \& Viswanathan, A. N. (2015). A radiopaque polymer hydrogel used as a fiducial marker in gynecologic-cancer patients receiving brachytherapy. Brachytherapy, 14(6), 876-880.

Balcerek, M., Reinmuth, S., Hohmann, C., Keil, T., \& Borgmann-Staudt, A. (2012). Suspected infertility after treatment for leukemia and solid tumors in childhood and adolescence. Deutsches Ärzteblatt International, 109(7), 126-131.

Baliga, M. S., Meera, S., Vaishnav, L. K., Rao, S., \& Palatty, P. L. (2013). Rasayana drugs from the Ayurvedic system of medicine as possible radioprotective agents in cancer treatment. Integrative Cancer Therapies, 12(6), 455-463.

Barber, J. B., Burrill, W., Spreadborough, A. R., Levine, E., Warren, C., Kiltie, A. E., ... Scott, D. (2000). Relationship between in vitro chromosomal radiosensitivity of peripheral blood lymphocytes and the expression of normal tissue damage following radiotherapy for breast cancer. Radiotherapy and Oncology, 55(2), 179-186.

Begg, A. C., Stewart, F. A., \& Vens, C. (2011). Strategies to improve radiotherapy with targeted drugs. Nature Reviews. Cancer, 11(4), 239-253.

Bendale, Y., Bendale, V., Birari-Gawande, P., Kadam, A., \& Gund, P. (2015). Tumor regression with ayurvedic rasayana therapy in squamous cell carcinoma of lungs. Rasamruta, 7, 1-5 http://rasamruta.com/pdf/PDF..15.pdf.

Bendale, Y., Bendale, V., Birari-Gawande, P., Kadam, A., Ladsongikar, K., \& Gund, P. (2015). Prognostic significance after use of Rasayana therapy in a colon cancer patient-a case report. Rasamruta, 7(6), 1-5.

Benveniste, M. F. K., Welsh, J., Godoy, M. C. B., Betancourt, S. L., Mawlawi, O. R., \& Munden, R. F. (2013). New era of radiotherapy: An update in radiationinduced lung disease. Clinical Radiology, 68(6), e275-e290. https://doi.org/10. 1016/j.crad.2013.01.013.

Bjordal, K., Kaasa, S., \& Mastekaasa, A. (1994). Quality of life in patients treated for head and neck cancer: A follow-up study 7 to 11 years after radiotherapy. International Journal of Radiation Oncology* Biology* Physics, 28(4), 847-856.

Bortfeld, T. (1991). Optimized planning using physical objectives and constraints. Seminars in Radiation Oncology, Elsevier 9, 1, 20-34. https://doi.org/10.1016/ S1053-4296(99)80052-6.

Brierley, J. D. (2011). Update on external beam radiation therapy in thyroid cancer. The Journal of Clinical Endocrinology and Metabolism, 96(8), 2289-2295.

Budach, W., Hehr, T., Budach, V., Belka, C., \& Dietz, K. (2006). A meta-analysis of hyperfractionated and accelerated radiotherapy and combined chemotherapy and radiotherapy regimens in unresected locally advanced squamous cell carcinoma of the head and neck. BMC Cancer, 6(1), 28.

Bujold, A., Craig, T., Jaffray, D., \& Dawson, L. A. (2012). Image-guided radiotherapy: Has it influenced patient outcomes?. Seminars in radiation oncology. WB Saunders 22, 1, 50-61 p. https://doi.org/10.1016/j.semradonc.2011.09.001.

Chandra, A., Guerrero, T. M., Liu, H. H., Tucker, S. L., Liao, Z., Wang, X., ... Chang, J. Y. (2005). Feasibility of using intensity-modulated radiotherapy to improve lung sparing in treatment planning for distal esophageal cancer. Radiotherapy and Oncology, 77(3), 247-253.

Charalambous, A., Lambrinou, E., Katodritis, N., Vomvas, D., Raftopoulos, V. Georgiou, M., ... Charalambous, M. (2017). The effectiveness of thyme honey for the management of treatment-induced xerostomia in head and neck cancer patients: A feasibility randomized control trial. European Journal of Oncology Nursing, 27, 1-8.

Cho, Y. H., Kim, S. Y., Woo, H. D., Kim, Y. J., Ha, S. W., \& Chung, H. W. (2015). Delayed numerical chromosome aberrations in human fibroblasts by low dose of radiation. International Journal of Environmental Research and Public Health, 12(12), 15162-15172.

Clivio, A., Fogliata, A., Franzetti-Pellanda, A., Nicolini, G., Vanetti, E., Wyttenbach, R., \& Cozzi, L. (2009). Volumetric-modulated arc radiotherapy for carcinomas of the anal canal: A treatment planning comparison with fixed field IMRT. Radiotherapy and Oncology, 92(1), 118-124.

Cozzi, L., Dinshaw, K. A., Shrivastava, S. K., Mahantshetty, U., Engineer, R., Deshpande, D. D., ... Fogliata, A. (2008). A treatment planning study comparing volumetric arc modulation with RapidArc and fixed field IMRT for cervix uteri radiotherapy. Radiotherapy and Oncology, 89(2), 180-191.

Cruz, F., \& Bellver, J. (2014). Live birth after embryo transfer in an unresponsive thin endometrium. Gynecological Endocrinology, 30(7), 481-484.

Dawson, L. A., McGinn, C. J., Normolle, D., Ten Haken, R. K., Walker, S., Ensminger, W., \& Lawrence, T. S. (2000). Escalated focal liver radiation and concurrent hepatic artery fluorodeoxyuridine for unresectable intrahepatic malignancies. Journal of Clinical Oncology, 18(11), 2210-2218.

Dayes, I. S., Whelan, T. J., Julian, J. A., Kuettel, M. R., Regmi, D., Okawara, G. S., . Dubois, S. (2006). Cross-border referral for early breast cancer: An analysis of radiation fractionation patterns. Current Oncology, 13(4), 124.

de Gonzalez, A. B., Curtis, R. E., Kry, S. F., Gilbert, E., Lamart, S., Berg, C. D., ... Ron, E. (2011). Proportion of second cancers attributable to radiotherapy treatment in adults: A cohort study in the US SEER cancer registries. The Lancet Oncology, 12(4), 353-360.

De Ruysscher, D., Faivre-Finn, C., Nestle, U., Hurkmans, C. W., Le Péchoux, C., Price, A., \& Senan, S. (2010). European Organisation for Research and Treatment of Cancer recommendations for planning and delivery of high-dose, highprecision radiotherapy for lung cancer. Journal of Clinical Oncology, 28(36), 5301-5310.

Dolezel, M., Odrazka, K., Zouhar, M., Vaculikova, M., Sefrova, J., Jansa, J., ... Kovarik, J. (2015). Comparing morbidity and cancer control after 3D-conformal (70/74 Gy) and intensity modulated radiotherapy (78/82 Gy) for prostate cancer. Strahlentherapie und Onkologie, 191(4), 338-346.

Eisbruch, A., Ten Haken, R. K., Kim, H. M., Marsh, L. H., \& Ship, J. A. (1999). Dose, volume, and function relationships in parotid salivary glands following conformal and intensity-modulated irradiation of head and neck cancer. International Journal of Radiation Oncology* Biology* Physics, 45(3), 577-587.

Fuss, M., Salter, B. J., Herman, T. S., \& Thomas Jr., C. R. (2004). External beam radiation therapy for hepatocellular carcinoma: Potential of intensitymodulated and image-guided radiation therapy. Gastroenterology, 127(5), S206-S217.

Gensheimer, M. F., \& Loo, B. W. (2017). Optimal radiation therapy for small cell lung cancer. Current Treatment Options in Oncology, 18(4), 21.

Gnoth, C., Godehardt, E., Frank-Herrmann, P., Friol, K., Tigges, J., \& Freundl, G. (2005). Definition and prevalence of subfertility and infertility. Human Reproduction, 20(5), 1144-1147.

Grade, M., Difilippantonio, M. J., \& Camps, J. (2015). Patterns of chromosomal aberrations in solid tumors. In Chromosomal instability in Cancer cells, (pp. 115-142). Cham: Springer.

Grills, I. S., Hugo, G., Kestin, L. L., Galerani, A. P., Chao, K. K., Wloch, J., \& Yan, D. (2008). Image-guided radiotherapy via daily online cone-beam CT substantially reduces margin requirements for stereotactic lung radiotherapy. International Journal of Radiation Oncology* Biology* Physics, 70(4), 1045-1056.

Grover, S., Hill-Kayser, C. E., Vachani, C., Hampshire, M. K., DiLullo, G. A., \& Metz, J. M. (2012). Patient reported late effects of gynecological cancer treatment. Gynecologic Oncology, 124(3), 399-403.

Habbema, J. D. F., Eijkemans, M. J., Nargund, G., Beets, G., Leridon, H., \& te Velde, E. R. (2009). The effect of in vitro fertilization on birth rates in western countries. Human Reproduction, 24(6), 1414-1419.

Harris, J. R., Lippman, M. E., Morrow, M., \& Osborne, C. K. (2014). Diseases of the breast, 5th edition. United States: Wolters Kluwer/Lippincott Williams \& Wilkins Health, 2014. 1224p. https://www.ncbi.nlm.nih.gov/nlmcatalog/101616539.

Haruna, F., Lipsett, A., \& Marignol, L. (2017). Topical management of acute radiation dermatitis in breast cancer patients: A systematic review and metaanalysis. Anticancer Research, 37(10), 5343-5353.

Heim, R. A., Lench, N. J., \& Swift, M. (1992). Heterozygous manifestations in four autosomal recessive human cancer-prone syndromes: Ataxia telangiectasia, xeroderma pigmentosum, Fanconi anemia, and Bloom syndrome. Mutation Research/Fundamental and Molecular Mechanisms of Mutagenesis, 284(1), 2536. https://doi.org/10.1016/0027-5107(92)90022-T.

Holt, A., van Vliet-Vroegindeweij, C., Mans, A., Belderbos, J. S., \& Damen, E. M. (2011). Volumetric-modulated arc therapy for stereotactic body radiotherapy of lung tumors: A comparison with intensity-modulated radiotherapy techniques. International Journal of Radiation Oncology* Biology* Physics, $81(5), 1560-1567$

Hoppe, B. S., Michalski, J. M., Mendenhall, N. P., Morris, C. G., Henderson, R. H. Nichols, R. C., ... Crociani, C. M. (2014). Comparative effectiveness study of patient-reported outcomes after proton therapy or intensity-modulated radiotherapy for prostate cancer. Cancer, 120(7), 1076-1082. 
Kadhim, M., Salomaa, S., Wright, E., Hildebrandt, G., Belyakov, O. V., Prise, K. M., \& Little, M. P. (2013). Non-targeted effects of ionising radiation-Implications for low dose risk. Mutation Research/Reviews in Mutation Research, 752(2), 84-98.

Kadhim, M. A., Macdonald, D. A., Goodhead, D. T., Lorimore, S. A., Marsden, S. J., \& Wright, E. G. (1992). Transmission of chromosomal instability after plutonium a-particle irradiation. Nature, 355(6362), 738.

Kanda, R. (1996). Comparison of the yields of translocations and dicentrics measured using conventional Giemsa staining and chromosome painting. International Journal of Radiation Biology, 69(6), 701-705.

Kaplan, M. I., Limoli, C. L., \& Morgan, W. F. (1997). Perpetuating radiation-induced chromosomal instability. Radiation Oncology Investigations: Clinical and Basic Research, 5(3), 124-128.

Kellas-Sleczka, S., Wojcieszek, P., \& Białas, B. (2012). Adjuvant vaginal brachytherapy as a part of management in early endometrial cancer. Journal of Contemporary Brachytherapy, 4(4), 247.

Kennedy, A., Nag, S., Salem, R., Murthy, R., McEwan, A. J., Nutting, C., ... Coldwell, D. (2007). Recommendations for radioembolization of hepatic malignancies using yttrium-90 microsphere brachytherapy: A consensus panel report from the radioembolization brachytherapy oncology consortium. International Journal of Radiation Oncology* Biology* Physics, 68(1), 13-23.

Kim, G. J., Chandrasekaran, K., \& Morgan, W. F. (2006). Mitochondrial dysfunction, persistently elevated levels of reactive oxygen species and radiation-induced genomic instability: A review. Mutagenesis, 21(6), 361-367.

Klein, E. A., Casey, G., \& Silverman, R. (2006). Genetic susceptibility and oxidative stress in prostate cancer: Integrated model with implications for prevention. Urology, 68(6), 1145-1151.

Kole, T. P., Aghayere, O., Kwah, J., Yorke, E. D., \& Goodman, K. A. (2012). Comparison of heart and coronary artery doses associated with intensitymodulated radiotherapy versus three-dimensional conformal radiotherapy for distal esophageal cancer. International Journal of Radiation Oncology* Biology* Physics, 83(5), 1580-1586.

Kuvar, N. A., Lambole, V. B., Shah, B. N., Shah, P. K., \& Shah, D. P. (2013). A valuable medicinal plant-Crataeva nurvala. Pharma Science Monitor, 4, 3(1), 210-227.

Land, C. E., Tokunaga, M., Koyama, K., Soda, M., Preston, D. L., Nishimori, I., \& Tokuoka, S. (2003). Incidence of female breast cancer among atomic bomb survivors, Hiroshima and Nagasaki, 1950-1990. Radiation Research, 160(6), 707-717.

Lau, W. Y., Sangro, B., Chen, P. J., Cheng, S. Q., Chow, P., Lee, R. C., ... Poon, R. T. (2013). Treatment for hepatocellular carcinoma with portal vein tumor thrombosis: The emerging role for radioembolization using yttrium-90. Oncology, 84(5), 311-318.

Lawremce, T. S., Dworzanin, L. M., Walker-Andrews, S. C., Andrews, J. C., Ten Haken, R. K., Wollmer, I. S., ... Ensminger, W. D. (1991). Treatment of cancers involving the liver and porta hepatis with external beam irradiation and intraarterial hepatic fluorodeoxyuridine. International Journal of Radiation Oncology• Biology• Physics, 20(3), 555-561.

Liapi, E., \& Geschwind, J. F. H. (2010). Intra-arterial therapies for hepatocellular carcinoma: Where do we stand? Annals of Surgical Oncology, 17(5), 1234-1246.

Lin, J. H. (2016). Review structure-and dynamics-based computational design of anticancer drugs. Biopolymers, 105(1), 2-9.

Lin, S. H., Wang, L., Myles, B., Thall, P. F., Hofstetter, W. L., Swisher, S. G., ... Liao, Z. (2012). Propensity score-based comparison of long-term outcomes with 3dimensional conformal radiotherapy vs intensity-modulated radiotherapy for esophageal cancer. International Journal of Radiation Oncology* Biology* Physics, 84(5), 1078-1085.

Little, J. B. (2003). Genomic instability and bystander effects: A historical perspective. Oncogene, 22(45), 6978.

Lorimore, S. A., \& Wright, E. G. (2003). Radiation-induced genomic instability and bystander effects: Related inflammatory-type responses to radiation-induced stress and injury? A review. International Journal of Radiation Biology, 79(1), 15-25.

Lu, L., Shan, F., Li, W., \& Lu, H. (2016, 2016). Short-term side effects after radioiodine treatment in patients with differentiated thyroid cancer. BioMed Research International, Volume 2016, Article ID 4376720, 5 pages. http://dx. doi.org/10.1155/2016/4376720.

Malmanche, N., Maia, A., \& Sunkel, C. E. (2006). The spindle assembly checkpoint: Preventing chromosome mis-segregation during mitosis and meiosis. FEBS Letters, 580(12), 2888-2895.

Malvika, S., Satyapal, S., Lal, J. M., \& Mita, K. (2016). An Ayurveda approach to combat toxicity of chemo-radiotherapy in cancer patients. International Journal of Research in Ayurveda and Pharmacy, 7(Suppl 2), 124-129.

McGinn, C. J., Ten Haken, R. K., Ensminger, W. D., Walker, S., Wang, S., \& Lawrence, T. S. (1998). Treatment of intrahepatic cancers with radiation doses based on a normal tissue complication probability model. Journal of Clinical Oncology, 16(6), 2246-2252.

McGregor, S., Minni, J., \& Herold, D. (2015). Superficial radiation therapy for the treatment of nonmelanoma skin cancers. The Journal of Clinical and Aesthetic Dermatology, 8(12), 12.

Ming, X., Feng, Y., Yang, C., Wang, W., Wang, P., \& Deng, J. (2016). Radiationinduced heart disease in lung cancer radiotherapy: A dosimetric update. Medicine, 95(41), e5051.

Misra, B. B., \& Dey, S. (2013). Biological activities of East Indian sandalwood tree, Santalum album (No. e96v1). In PeerJ PrePrints.

Morgan, W. F., Day, J. P., Kaplan, M. I., McGhee, E. M., \& Limoli, C. L. (1996), Genomic instability induced by ionizing radiation. Radiation Research, 146(3), 247-258.

Nakayama, M., Okizaki, A., \& Takahashi, K. (2016). A randomized controlled trial for the effectiveness of aromatherapy in decreasing salivary gland damage following radioactive iodine therapy for differentiated thyroid cancer. BioMed Research International, Volume 2016, Article ID 9509810,6 pages. http://dx.doi. org/10.1155/2016/9509810.

Nguyen, N. P., Chi, A., Betz, M., Almeida, F., Vos, P., Davis, R., .. Stevie, M. (2012). Feasibility of intensity-modulated and image-guided radiotherapy for functional organ preservation in locally advanced laryngeal cancer. PLoS One, 7(8), e42729.

Niyazi, M., Maihoefer, C., Krause, M., Rödel, C., Budach, W., \& Belka, C. (2011). Radiotherapy and "new" drugs-new side effects? Radiation Oncology, 6(1), 177.

Nutting, C., Dearnaley, D. P., \& Webb, S. (2000). Intensity modulated radiation therapy: A clinical review. The British Journal of Radiology, 73(869), 459-469.

Nutting, C. M., Bedford, J. L., Cosgrove, V. P., Tait, D. M., Dearnaley, D. P., \& Webb, S. (2001). A comparison of conformal and intensity-modulated techniques for oesophageal radiotherapy. Radiotherapy and Oncology, 61(2), 157-163.

Orth, M., Lauber, K., Niyazi, M., Friedl, A. A., Li, M., Maihöfer, C., ... Belka, C. (2014). Current concepts in clinical radiation oncology. Radiation and Environmental Biophysics, 53(1), 1-29.

Palatty, P. L., Azmidah, A., Rao, S., Jayachander, D., Thilakchand, K. R., Rai, M. P., ... D'souza, P. F. (2014). Topical application of a sandal wood oil and turmeric based cream prevents radiodermatitis in head and neck cancer patients undergoing external beam radiotherapy: A pilot study. The British Journal of Radiology, 87(1038), 20130490.

Palma, D., Vollans, E., James, K., Nakano, S., Moiseenko, V., Shaffer, R., ... Otto, K. (2008). Volumetric modulated arc therapy for delivery of prostate radiotherapy: Comparison with intensity-modulated radiotherapy and threedimensional conformal radiotherapy. International Journal of Radiation Oncology* Biology* Physics, 72(4), 996-1001.

Pradier, O., Christiansen, H., Ambrosch, P., Kron, M., Schmidberger, H., \& Hess, C. F. (2004). A long-term follow-up study after split-course irradiation with concurrent chemotherapy (carboplatin) for locally advanced head and neck cancer and a review of the literature. ORL, 66(6), 325-331.

Prasanna, P. G., Narayanan, D., Hallett, K., Bernhard, E. J., Ahmed, M. M., Evans, G., ... Coleman, C. N. (2015). Radioprotectors and radiomitigators for improving radiation therapy: The small business innovation research (SBIR) gateway for accelerating clinical translation. Radiation Research, 184(3), 235-248.

Preston, D. L., Shimizu, Y., Pierce, D. A., Suyama, A., \& Mabuchi, K. (2003). Studies of mortality of atomic bomb survivors. Report 13: Solid cancer and noncancer disease mortality: 1950-1997. Radiation Research, 160(4), 381-407.

Rai, B., Bansal, A., Patel, F. D., \& Sharma, S. C. (2014). Radiotherapy for ovarian cancersredefining the role. Asian Pacific Journal of Cancer Prevention, 15(12), 4759-4763.

Raviraj, J., Bokkasam, V. K., Kumar, V. S., Reddy, U. S., \& Suman, V. (2014). Radiosensitizers, radioprotectors, and radiation mitigators. Indian Journal of Dental Research, 25(1), 83.

Robertson, J. M., Lawrence, T. S., Dworzanin, L. M., Andrews, J. C., Walker, S., Kessler, M. L., ... Ensminger, W. D. (1993). Treatment of primary hepatobiliary cancers with conformal radiation therapy and regional chemotherapy. Journal of Clinical Oncology, 11(7), 1286-1293.

Rong, Y., Zuo, L., Shang, L., \& Bazan, J. G. (2015). Radiotherapy treatment for nonmelanoma skin cancer. Expert Review of Anticancer Therapy, 15(7), 765-776.

Salem, R., Lewandowski, R. J., Mulcahy, M. F., Riaz, A., Ryu, R. K., Ibrahim, S., ... Sato, K. T. (2010). Radioembolization for hepatocellular carcinoma using Yttrium-90 microspheres: A comprehensive report of long-term outcomes. Gastroenterology, 138(1), 52-64.

Sanda, M. G., Dunn, R. L., Michalski, J., Sandler, H. M., Northouse, L., Hembroff, L., ... Mahadevan, A. (2008). Quality of life and satisfaction with outcome among prostate-cancer survivors. New England Journal of Medicine, 358(12), 1250-1261. 
Sandberg, A. A. (1991). Chromosome abnormalities in human cancer and leukemia. Mutation Research/Fundamental and Molecular Mechanisms of Mutagenesis, 247(2), 231-240.

Sangro, B., Iñarrairaegui, M., \& Bilbao, J. I. (2012). Radioembolization for hepatocellular carcinoma. Journal of Hepatology, 56(2), 464-473.

Sato, K., Lewandowski, R. J., Bui, J. T., Omary, R., Hunter, R. D., Kulik, L., ... Nemcek, A. A. (2006). Treatment of unresectable primary and metastatic liver cancer with yttrium-90 microspheres (TheraSphere ${ }^{\oplus}$ ): Assessment of hepatic arterial embolization. Cardiovascular and Interventional Radiology, 29(4), 522-529.

Sen, S. (2000). Aneuploidy and cancer. Current Opinion in Oncology, 12(1), 82-88.

Shaffer, R., Nichol, A. M., Vollans, E., Fong, M., Nakano, S., Moiseenko, V., ... Otto, K. (2010). A comparison of volumetric modulated arc therapy and conventional intensity-modulated radiotherapy for frontal and temporal high-grade gliomas. International Journal of Radiation Oncology* Biology* Physics, 76(4), 1177-1184.

Shoma, A., Eldars, W., Noman, N., Saad, M., Elzahaf, E., AbdAlla, M., ... Abdel Malek, H. (2010). Pentoxifylline and local honey for radiation-induced burn following breast conservative surgery. Current Clinical Pharmacology, 5(4), 251-256.

Sontakke, S., Thawani, V., \& Naik, M. S. (2003). Ginger as an antiemetic in nausea and vomiting induced by chemotherapy: A randomized, cross-over, double blind study. Indian Journal of Pharmacology, 35(1), 32-36.

Sprung, C. N., Chao, M., Leong, T., \& McKay, M. J. (2005). Chromosomal radiosensitivity in two cell lineages derived from clinically radiosensitive cancer patients. Clinical Cancer Research, 11(17), 6352-6358.

Sprung, C. N., Davey, D. S., Withana, N. P., Distel, L. V., \& McKay, M. J. (2008). Telomere length in lymphoblast cell lines derived from clinically radiosensitive cancer patients. Cancer Biology and Therapy, 7(5), 638-644.

Sprung, C. N., Ivashkevich, A., Forrester, H. B., Redon, C. E., Georgakilas, A., \& Martin, O. A. (2015). Oxidative DNA damage caused by inflammation may link to stress-induced non-targeted effects. Cancer Letters, 356(1), 72-81.

Thun, M. J., DeLancey, J. O., Center, M. M., Jemal, A., \& Ward, E. M. (2009). The global burden of cancer: Priorities for prevention. Carcinogenesis, 31(1), 100-110.

Tomita, M., \& Maeda, M. (2015). Mechanisms and biological importance of photon-induced bystander responses: Do they have an impact on low-dose radiation responses. Journal of Radiation Research, 56(2), 205-219.

Tsujii, H. (2017). Overview of carbon-ion radiotherapy. Journal of Physics: Conference Series, 777(1), 012032 IOP Publishing.

Tubiana, M. (2009). Can we reduce the incidence of second primany malignancies occurring after radiotherapy? A critical review. Radiotherapy and Oncology, 91(1), 4-15.

UNSCEAR, A (2000). United Nations Scientific Committee on the Effects of Atomic Radiation. Sources and effects of ionizing radiation, (p. 2).

Van Schaeybroeck, S., Karaiskou-McCaul, A., Kelly, D., Longley, D., Galligan, L., Van Cutsem, E., \& Johnston, P. (2005). Epidermal growth factor receptor activity determines response of colorectal cancer cells to gefitinib alone and in combination with chemotherapy. Clinical Cancer Research, 11(20), 7480-7489.

Verbakel, W. F., Cuijpers, J. P., Hoffmans, D., Bieker, M., Slotman, B. J., \& Senan, S. (2009). Volumetric intensity-modulated arc therapy vs. conventional IMRT in head-and-neck cancer: A comparative planning and dosimetric study. International Journal of Radiation Oncology* Biology* Physics, 74(1), 252-259.

Vicini, F., Kestin, L., Ghilezan, M., \& Martinez, A. (2006). Radiation dose for prostate cancer: Is more better? Nature Reviews Clinical Oncology, 3(6), 298.

Wo, J. Y., \& Viswanathan, A. N. (2009). Impact of radiotherapy on fertility, pregnancy, and neonatal outcomes in female cancer patients. International Journal of Radiation Oncology* Biology* Physics, 73(5), 1304-1312.

Xi, M., Liu, S. L., Zhao, L., Shen, J. X., Zhang, L., Zhang, P., \& Liu, M. Z. (2013). Prognostic factors and survival in patients with radiation-related second malignant neoplasms following radiotherapy for nasopharyngeal carcinoma. PLoS One, 8(12), e84586.

Yeh, S. A. (2010). Radiotherapy for head and neck cancer. Seminars in plastic surgery. Thieme Medical Publishers. 24, 2, 127-136p. https://doi.org/10.1055/ s-0030-1255330.

Yu, S. J., \& Kim, Y. J. (2015). Effective treatment strategies other than sorafenib for the patients with advanced hepatocellular carcinoma invading portal vein. World Journal of Hepatology, 7(11), 1553.

Zaletel, L. Z., Todorovski, L., \& Jereb, B. (2012). Hypogonadism after childhood cancer treatment. Sex Hormones, 161-196p. InTech. https://doi.org/10.5772/ 34194, http://cdn.intechopen.com/pdfs/27783/InTech-Hypogonadism_after_ childhood_cancer_treatment.pdf
Zhang, W., \& Hayata, I. (2003). Preferential reduction of dicentrics in reciprocal exchanges due to the combination of the size of broken chromosome segments by radiation. Journal of Human Genetics, 48(10), 531.

Zietman, A. L., DeSilvio, M. L., Slater, J. D., Rossi, C. J., Miller, D. W., Adams, J. A., \& Shipley, W. U. (2005). Comparison of conventional-dose vs high-dose conformal radiation therapy in clinically localized adenocarcinoma of the prostate: A randomized controlled trial. JAMA, 294(10), 1233-1239. https://doi. org/10.1001/jama.294.10.1233.

\section{Submit your manuscript to a SpringerOpen ${ }^{\odot}$ journal and benefit from:}

- Convenient online submission

- Rigorous peer review

- Open access: articles freely available online

- High visibility within the field

- Retaining the copyright to your article

Submit your next manuscript at $>$ springeropen.com 